\title{
Self-Portrait with the Spanish Flu
}

The scream evokes the dream I dread.

"I want to sit up," you had said, regarding the chair.

I carried you there

from the bed.

Tears were shed

but not by you. You drew cold air and shut your eyes, ever the fair sister I adore.

The halos of your

backlit hair

led my stare

from their gilt sheaves to the cracked score of the window-panes' ferny hoar frost. Your soul, wrested from its maidenhead, found the door. Metaphor.

This phthisis has disquieted the Muses and dispirited, yea, Apollinaire, his devil-may-care and hurt head, shepherded

to futter the fields of trouvère.

Endless black weddings fill the air with song and implore the dispatch of warlike despair; everywhere,

we fall sick with fevers that pour gloom into us and dull the core of bright hues that fed on what painters bled from a door heretofore.

\section{Mark Olival-Bartley}




\section{About the Poem and the Poet}

Comprising six syllabic sestets of a Welsh form called clogyrnach, this ekphrastic poem is a dramatic monologue that imagines the mindset of Edvard Munch in his SelfPortrait with the Spanish Flu, which was painted in 1919 when the artist was fifty-six years old. The first three stanzas allude to a lifelong trauma caused by witnessing the tubercular death of Sophie, his favorite sibling; the chair depicted is the same wherein she died, which, incidentally, is on view at Oslo's Munch Museum. Having survived injuries sustained in the First World War, surrealist poet Guillaume Apollinaire contracted the influenza A virus, subtype H1N1, and died in November 1918 at the age of thirty-eight. A black wedding-often referred to by its Yiddish term, shvartze khasene-was an ancient Jewish rite to ward off an infectious epidemic through a communityfunded marriage ceremony between two indigent strangers that took place in a cemetery.

Mark Olival-Bartley is the poet in residence at EcoHealth Alliance. He tutors composition, creative writing, and American literature at LMU Munich, where he is presently writing his dissertation on E. A. Robinson's metasonnet.

\section{About the Art and the Artist}

Edvard Munch contracted the Spanish flu at the end of 1918 and documented the illness in a series of sketches and paintings. With a sallow complexion and thinning hair, Munch is sitting in a wicker chair in front of his unmade bed, illustrating his frail condition. The figure is depicted using simple lines and minimal colors applied with rough sweeps of the brush. The small room evokes a feeling of confinement, and the dominant use of yellow intensifies the restlessness of the composition.

Edvard Munch was born in 1863, in Löten, Norway, and was a key artist of the Expressionism movement. Closely associated with Symbolism, he is best known for his images of isolation, anxiety, sensuality, rejection and death, many of which reflected his neurotic and tragic life.

\section{ACKNOWLEDGEMENTS}

Open Access funding provided by Projekt DEAL.

\section{OPEN Access}

This article is licensed under a Creative Commons Attribution 4.0 International License, which permits use, sharing, adaptation, distribution and reproduction in any medium or format, as long as you give appropriate credit to the original author(s) and the source, provide a link to the Creative Commons licence, and indicate if changes were made. The images or other third party material in this article are included in the article's Creative Commons licence, unless indicated otherwise in a credit line to the material. If material is not included in the article's Creative Commons licence and your intended use is not permitted by statutory regulation or exceeds the permitted use, you will need to obtain permission directly from the copyright holder. To view a copy of this licence, visit http://creativec ommons.org/licenses/by/4.0/. 